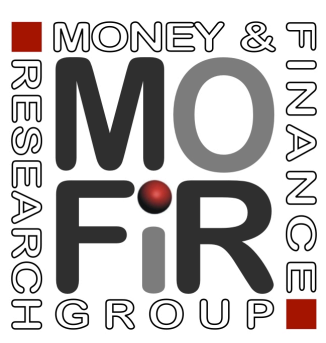

\title{
BANK FOUNDATIONS, SOCIAL CAPITAL, AND THE GROWTH OF ITALIAN PROVINCES
}

\section{Giorgio Calcagnini Germana Giombini \\ Francesco Perugini}

Working paper no. 131

November 2016 


\title{
Bank Foundations, Social Capital, and the Growth of Italian Provinces
}

\author{
Giorgio Calcagnini, ${ }^{\mathrm{a}}$ Germana Giombini, ${ }^{\mathrm{a}}$ Francesco Perugini ${ }^{\mathrm{b}}$ \\ Department of Economics, Society, and Politics \\ Università di Urbino Carlo Bo \\ Via Saffi 42, 61029 Urbino, Italy
}

\begin{abstract}
The funding role of Bank Foundations in the Italian economy, especially to the non-profit sector, significantly increased over the last twenty-five years. By means of a novel measure of social capital, our paper evaluates the contribution of Bank Foundations to the economic development of Italian provinces. Our findings suggest that Bank Foundations positively affect social capital and the economic growth of provinces.
\end{abstract}

Keywords: Bank Foundations; social capital; economic growth.

JEL Classification: G23, O47, C13, R11.

\footnotetext{
${ }^{\mathrm{a}}$ And Mo.Fi.R., Ancona.

${ }^{\mathrm{b}}$ Corresponding author: Francesco Perugini, Via Saffi 42, 61029 Urbino, Italy. e-mail: francesco.perugini@uniurb.it. tel. +390722 305557, fax: +390722 305541.
} 


\section{Introduction}

The Italian economic dualism and the evolution of regional per-capita income in Italy have been attracting interest and debate among scholars for many years. Empirical work shows a weak conditional convergence process and almost no absolute convergence across Italian regions. It is often argued that, while regional or provincial disparities in per-capita GDP and productivity significantly decreased from the beginning of the 60 's to the earlier years of the 70's, in the subsequent decades such disparities remained stable or, during specific period of time, increased. Only in recent years, notably during the second half of the 1990s, has a convergence in productivity and, to a lesser extent in per-capita GDP, taken place. As a result, the evidence points to a persistent gap in income levels between provinces located in Northern Italy and those located in the South. ${ }^{1}$

These wide and persistent income differences are often related to the geographical distribution of social capital. In his 1993 seminal paper, Putnam analyzes how differences in social capital endowments across regions may explain why Northern regions, that are endowed by higher levels of social capital, also show higher levels of per-capita income.

Following Putnam influential work, an extensive body of research has evolved to relate income divergence between regions or countries to differences in social capital, showing that it generally exerts a positive effect both on income levels and on growth rates. For example, Beugelsdijk and Van Schaik (2005) show large regional differences in the social capital index among European regions and a positive relationship between social capital and regional economic development. Recently, Peiró-Palonimo (2016) analyzes the role of two social capital indexes on the economic growth of 237 European regions in the period 1995-2007 and shows the presence of heterogenous effects across regions and over time. Iyer et al. (2005) examine the role of social capital in 40 USA communities and find remarkable diversity of social capital across regions. ${ }^{2}$

As for the Italian case, Guiso et al. (2004) show that social capital contributes to economic prosperity, and that differences in social capital and in the level of trust across Italian provinces also explain differences in their financial development. Similarly, De Blasio and Nuzzo (2006) find that social capital is a determinant of worker productivity, entrepreneurship and female labour market participation, all of which are trust-sensitive. Furthermore, the same authors show that higher social capital endowment reduces inequality, while individuals tend to show more social behavior in those regions characterized by less uneven income distribution (De Blasio and Nuzzo 2010 and 2012).

Other studies find a positive relationship between social capital and innovation across Italian provinces (Crescenzi et al. 2013). The positive relationship also extends to income (Rizzi and Popara, 2006), the living standards (Andriani and Karyampas, 2009), the occupational choices of workers (Ferrante and Sabatini, 2007), and the performance of exports and employment across Italian provinces/regions (Mazzola et al. 2012). Further, Buonanno et al. (2009) and Arrighetti and Lasagni (2010) find that a higher level of social capital, measured by civic norms and associational networks, may exert a positive effect on economic activities through a significant reduction in crime rates or the level of corruption (Del Monte and Papagni 2007). Peiró-Palonimo and Tortosa-Ausina (2015)

\footnotetext{
${ }^{1}$ See for instance, Arbia et al (2002), Magrini (2007), and Morana (2004), among others.

${ }^{2}$ See also Cooke et al. (2005) for the UK case.
} 
show that, in the context of Spanish provinces, social capital has a positive impact on GDP per capita growth, implying that 'social features' are important for explaining the differences in wealth that one might find across Spanish provinces. Finally, Camagni (2008) and Perucca (2013) showed that the endowment of regional social capital can explain recent economic performances of Italian provinces.

Our study contributes to the literature on income disparities and institutional performance between Northern and Southern Italian provinces by analyzing the role of Bank Foundations (Fondazioni di origine bancaria, hereinafter BFs) as a source of social capital and, in turn, economic development. Indeed, it is widely recognized that BFs play an important role in improving the quality of life, and encouraging initiatives of social utility by guaranteeing financial support through direct or grant-making activities, creating a stable and exclusive relationship with a multitude of actors and the local communities and by establishing a network for sharing knowledge and expertise (Bandera 2013, Barbetta 2013). Therefore, we expect that BFs have a direct impact on economic activity, especially in those sectors of the economy mostly penalized by the market such as arts and public cultural activities (Di Lascio and Segre 2008, Funari and Rizzi 2003), and on local economic growth (Irpet 2011).

To our knowledge this paper is the first attempt that empirically evaluates the extent to which BFs grant-making activities influence economic growth of Italian provinces.

This paper improves on previous literature on several ways. First, we provide a novel measure of social capital at provincial level based on a set of variables that explicitly takes into account the BFs sectors of intervention (such as education, public health, etc.) together with other traditional aspects of social capital (such as political participation rates and the number of voluntary members in non-profit organizations). Then, these variables are aggregated in eight sectoral indexes by means of the Principal Component Analysis (PCA). Finally, the eight indexes are aggregated in a synthetic weighted index of social capital by using the proportion of funds received by each sector as weights. Our measure has a geographical distribution that shows decreasing endowments of social capital moving from the Northern provinces to the Southern ones.

Second, we shed light on the role of BFs grant-making activities on local development by directly estimating the impact of BFs grants on provincial social capital. To this purpose, we use both ordinary least square and quantile regressions to control for possible nonlinearities of the impact of BFs funds on social capital. As expected, our findings suggest a positive relationship between BFs funds and social capital.

Finally, we analyze the role of BFs funding activities on income growth of Italian provinces. By means of GMM techniques, and controlling for a full set of growth determinants, we find that the impact of BFs grants on income growth is positive and statistically significant.

In a period characterized by a weakening of the overall economic conditions, we shed light on the role of BFs as engine of local growth. In term of policy implications, our findings suggest that BFs have been a key element in determining social capital and wealth, and thus their grant-making activity should be not only preserved but widespread.

The rest of the paper is organized as follows. Next Section describes the context and data used, and briefly discusses the role of FBs in Italy, while in Section 3 we derive the new index of social capital at provincial level focusing on those activities that are closely related to the presence of BFs. In Section 4 we present the empirical models and analyze the impact of BFs grants on social capital and on the economic growth of Italian 
provinces. Section 5 concludes.

\section{The Italian context: economic dualisms and bank foun- dations in Italy}

We analyze the role of BFs grant-making activities on social capital and economic growth of Italian provinces during the period 2001-2011, combining information from different data sources. ${ }^{3}$

\section{Local economic growth}

Data on per-capita Value Added (VA) are taken from ISTAT. Per-capita VA reveals that over the last decade income disparities remained persistent across Italian provinces. ${ }^{4}$ Figure 1 Panel (a) shows the per-capita VA at the beginning of the period (2001), while Panel (b) the per-capita VA in 2011. It is clear, by comparing the two Panels, the remarkable and stable dualism between Northern and Southern provinces, with the richest provinces located in the North of Italy. In the same period, the ratio between the average level of per-capita VA of the provinces located in the South and the provinces located in the North remained stable, at around 62\%. However, Panel (c) of Figure 1 shows an irregular pattern of the distribution of per-capita VA growth, which suggests that some provinces have performed better than others, irrespective of their geographical location.

\section{Bank foundations}

Information on BFs are provided by the Italian Association of Foundations and Savings Banks (ACRI). BFs are a quite recent phenomenon in the Italian scenario. They were first established in the Italian legal system in 1990 by means of the so called 'AmatoCarli' delegated law aimed at restructuring and adapting the Italian credit system to the changed economic environment. ${ }^{5}$ Since then, the Italian BFs are operating institutions that manage their endowments in order to directly provide services to different groups of beneficiaries in fields such as health, culture, education, and social services. The reform produced a separation of credit business from philanthropic activities: the banking business passed to the savings banks, while activities concerned with social, cultural, civil and economic development remained with the newly created foundations. A series of reforms and progressive transformations followed and changed the nature of foundations and their relationship with their original banks. ${ }^{6}$

\footnotetext{
${ }^{3}$ See also Table A2 of the Data Appendix.

${ }^{4}$ Italian provinces correspond to the European NUTS-3 level in the Eurostat classification. During the period 2001-2011, the number, the political and geographical structure of Italian provinces changed. In this paper, we were able to assemble a complete dataset only for 100 provinces.

${ }^{5}$ Delegated law n.218 of July 30th 1990.

${ }^{6}$ In 1994 the introduced law n.474 (Dini directive) set incentives to reduce control on banks. In 1998 law n.461 (Ciampi law) and in 1999 the decree n.153 required foundations to relinquish any remaining control in their respective banks. In 2001 the sponsored law 448 (Tremonti law) limited the private nature and the statutory autonomy of foundations, but in September 2003 the Constitutional Court reaffirmed foundations as "private, legal entities having statutory and management autonomy".
} 
Figure 1: From left: geographical distribution of a) 2001 per-capita VA;

b) 2011 per-capita VA; c) per-capita VA growth (period average).

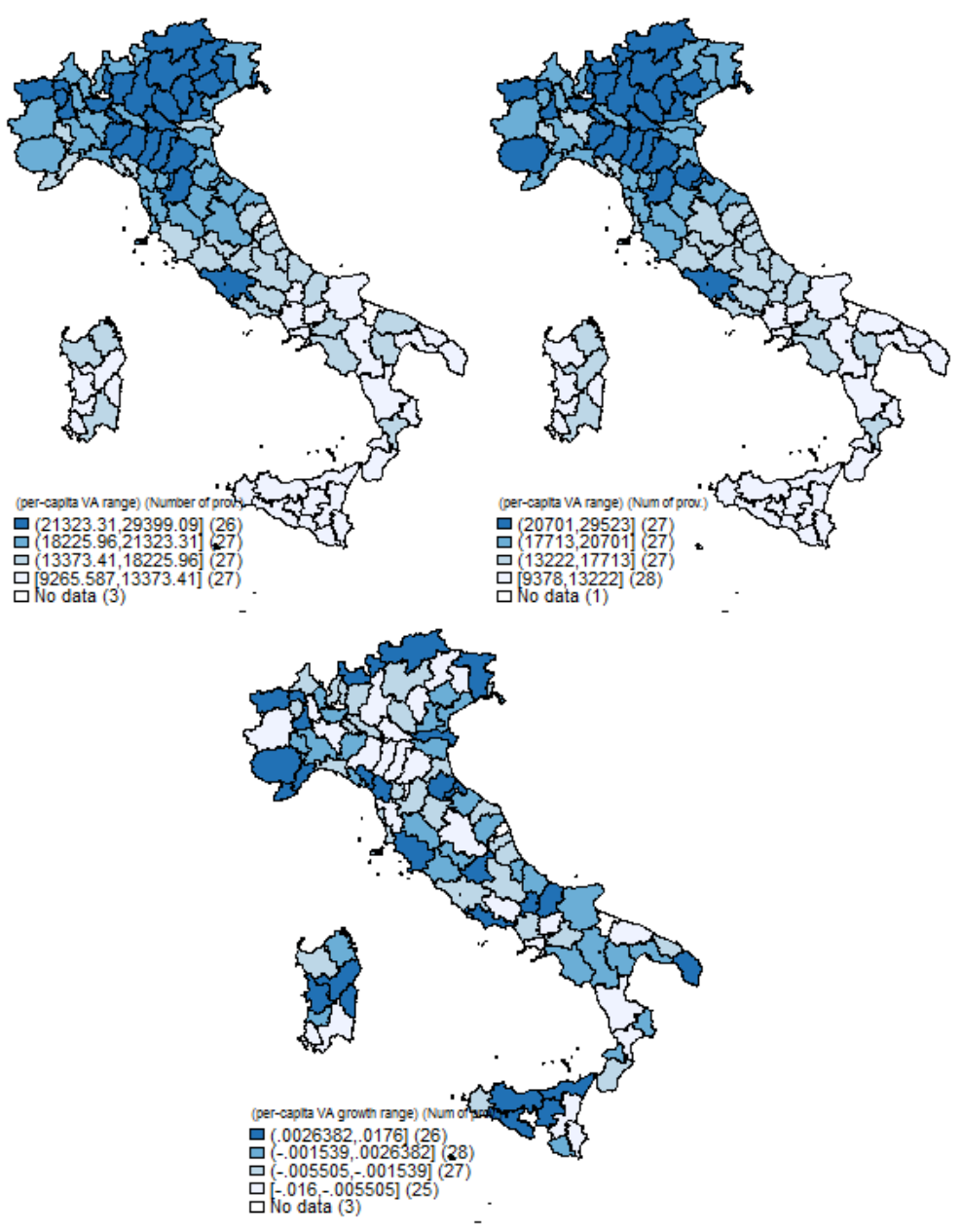

In 201188 BFs were operating in Italy. They vary in size and location, reflecting the history and the success of the bank they originated from. In 2011 they represented about $€ 43$ billion in assets, about $2 \%$ of GDP, with the five largest foundations holding about half of the total assets. ${ }^{7}$

According to official data released by ACRI, BFs have distributed, on average between 2001-2011, at least $€ 1$ billion per year, for a total of about $€ 15$ billion and 280 thousands projects financed. Grants making constantly increased until the onset of the economic and financial crisis that started in 2008 and hit banks and their ability to pay dividends, and that ultimately impacted BFs' cash flows.

Regarding the geographical distribution of grants, during the period 2001-2011 the North of Italy received on average almost $68 \%$ of total funds, the Centre received $26 \%$, while the South received about 3\% (Figure 2a). ${ }^{8}$ Since BFs activities and grant-making

\footnotetext{
${ }^{7}$ This is a relatively small figure compare to international standards. The first 10 US Foundations have almost twice as much assets as the Italian ones (see Filtri and Guglielmi, 2012). Nevertheless, BFs are vital for specific sectors, such as the preservation of Italy's artistic heritage.

${ }^{8}$ The remaining $3 \%$ cannot be assigned to a single province or region.
} 
Figure 2: From left: a) Total amount of BFs grants received by provinces (2001-2011 period); b) BFs geographical distribution in 2011
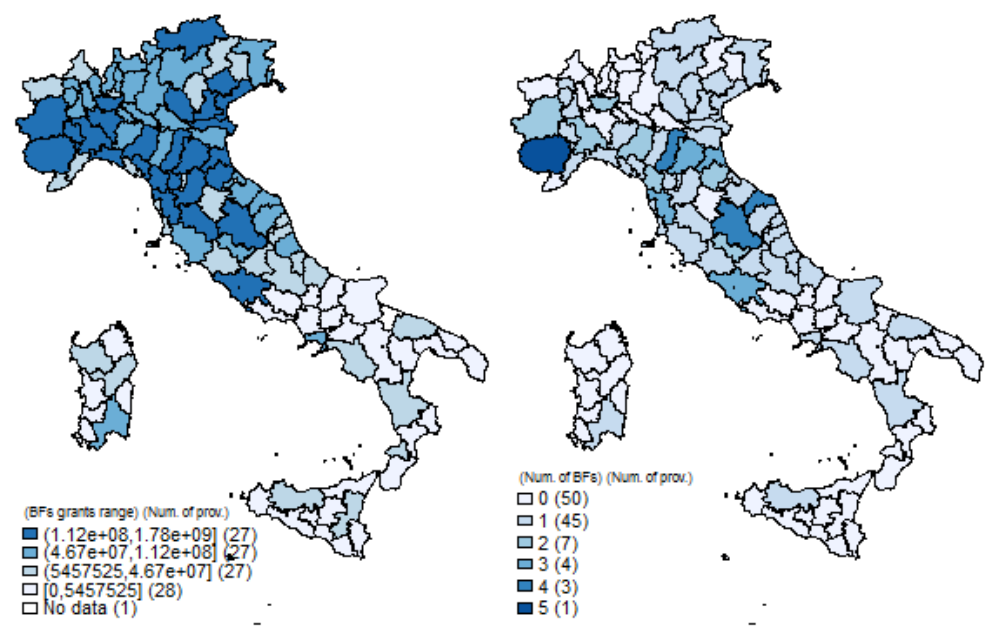

focus mainly on their local communities, the grant distribution mirrors their geographical location. Indeed, as shown in Figure 2b, BFs are predominantly located in the North of Italy: 47 of them are settled in this area, 30 in the Centre and 11 in the South (ACRI, 2011). On average, grants provided by BFs to the regions where they are located accounted for the great majority of the total funds ( $88 \%$ of funding and $94 \%$ of projects). Further, $58 \%$ of total funding and $73 \%$ of projects is accounted for by the same province where a BF is located. It is worth noting that the distribution of BFs and grants of Figure 2 mirrors closely the distribution on income across Italian provinces as shown in Figure 1.

\section{BFs sectors of intervention and selected variables}

BFs are required by the Italian law to fund specific sectors and release an annual mission report, i.e., a management report that describes various aspects of their activities. ${ }^{9}$ The Italian law also required BFs to spend at least $50 \%$ of total grants to five relevant sectors, which implies a high degree of sectoral specialization. In other words, despite the statutory independence, all Italian BFs tend to have the same priorities in allocating their grants. ${ }^{10}$ Over the period 2001-2011, about $€ 4.5$ billion were allocated to the cultural and artistic sector, accounting for more than $30 \%$ of grants. This funding concentration reflects a natural tendency of BFs to promote cultural and social heritage in the province where they are located. Other relevant sectors include education, research and technology, family and social services, and charity. Each of them received grants for about $€ 1,8$ billions ( $12 \%$ of the total) over the entire period.

In our study we focus on the eight main sectors of intervention selected by BFs for

\footnotetext{
${ }^{9}$ The Italian law pinpoints 21 fields or sectors qualified to receive financial support by BFs. Other fields not explicitly addressed by the law or the Ministry of Economic Affairs and Finance are left to the BFs.

${ }^{10}$ According to ACRI (2011), BFs is defined as "high" specialized when the amount of grant to a sector is at least $50 \%$ (or at least $60 \%$ for the first two sectors) of its total grants. It has a "medium" level of specialization when this ratio is $30 \%$ (40\%). Low in the other cases.
} 
their grant-making activities, which are: (1) Art and Culture; (2) Education; (3) Family and Social Services; (4) Research and Technology; (5) Charity; (6) Local Development; (7) Public Health; and (8) Environmental Protection, Sports, and other sectors.

To construct our index of social capital we select a total of 29 variables that explicitly takes into account the BFs sectors of intervention (such as education, public health, etc.) together with other more traditional aspects of social capital (such as political participation rates and the number of voluntary members in non-profit organizations). Table 1 describes for each sector of intervention the selected variables and their source.

The variable selection process at provincial level also depends on data availability. Indeed, most studies at regional level rely on specific surveys elaborated by the Italian national statistical institute (ISTAT) that do not provide information for provinces.

Thus, the variables selected for the Art and Culture sector (labelled as 1,2 and 3 in Table 1) capture characteristics of social capital related to social participation and social network, as well as the variables related to the Charity sector (labelled as 14, 15 and 16). ${ }^{11}$

As for Education, which is one of the relevant BFs sectors of intervention, we choose two measures of education attainment (labelled as 4 and 5) and two measures of education accumulation (labelled as 6 and 7 in Table 1). As for their relationship with social capital, empirical studies show that these variables have a positive impact on social capital and civic participation. Indeed, education may directly promote social capital accumulation by helping individuals to develop the civic skills and cognitive capacities that facilitate participation in groups and associations. It may also do so indirectly by lowering the opportunity costs of engaging in civic activities (Milligan et al., 2004; Dee, 2004).

Moreover, the variables chosen for the Family and Social Services sector (labelled as 8,9 and 10), together with other variables related to the eighth sector of intervention (labelled from 23 to 26 again in Table 1), capture individual involvement in local and national affairs that reflects civic and political participation, might influence social capital. $^{12}$

As for Research and Technology (see variables labelled from 11 to 13 in Table 1), the empirical literature detects a positive relationship between firms innovation performance and social capital, defined as civic and social interactions, finding a causal effect according to which more innovative firms are more likely to exchange information and interact with mutual benefits, thus creating a virtuous cycle based on cooperation and trust, and stimulating civicness and a sense of community (Hauser et al., 2007; Tura and Harmaakorpi, 2005).

As for Local Development variables (labelled as 17, 18 and 19), rising economic development can increase the ability of people to engage in community and associational activities that lead to higher levels of social capital and, in the process, more economic development, just as rising incomes increase the ability of people to engage in leisure activities (Jordan et al., 2010).

Regarding the Health variables (labelled as 20, 21 and 22), the empirical literature

\footnotetext{
${ }^{11}$ Furthermore, other variables also proxy opportunities for meetings in public places that enhance personal contacts and interactions, such as the frequency of seeing relatives, friends or neighbors, the extent of virtual networks and frequency of contact, the number of close friends, relatives who live nearby. However, these variables are not available at provincial level.

${ }^{12}$ Guiso, Sapienza and Zingales (2004) noted that, besides blood donations, participation in referenda does not depend on formal enforcement mechanisms, but they are merely an expression of social capital.
} 
identifies a number of pathways that link health status to social capital. For instance Sirven and Debrand (2011) show that the cohort of people who turned 50 in good health has a higher propensity to take part in social activities and to benefit from it. Further, Fiorillo (2008) shows that unhealthy people may find social interactions more difficult than healthy ones. There is also a reciprocal effect between health status and social capital because we may expect that higher levels of social capital favor healthier lifestyles.

Finally, variables referred to the Environmental protection sector (labelled as 27, 28 and 29 in Table 1) reflect the characteristics of the local area that might contribute to determine the territorial social capital, which is the system of territorial economic, cultural, social and environmental assets that ensures the potential development of places (OECD, 2001). For example, these variables are proxies for the level of trust a person has in other people or in formal institutions. 


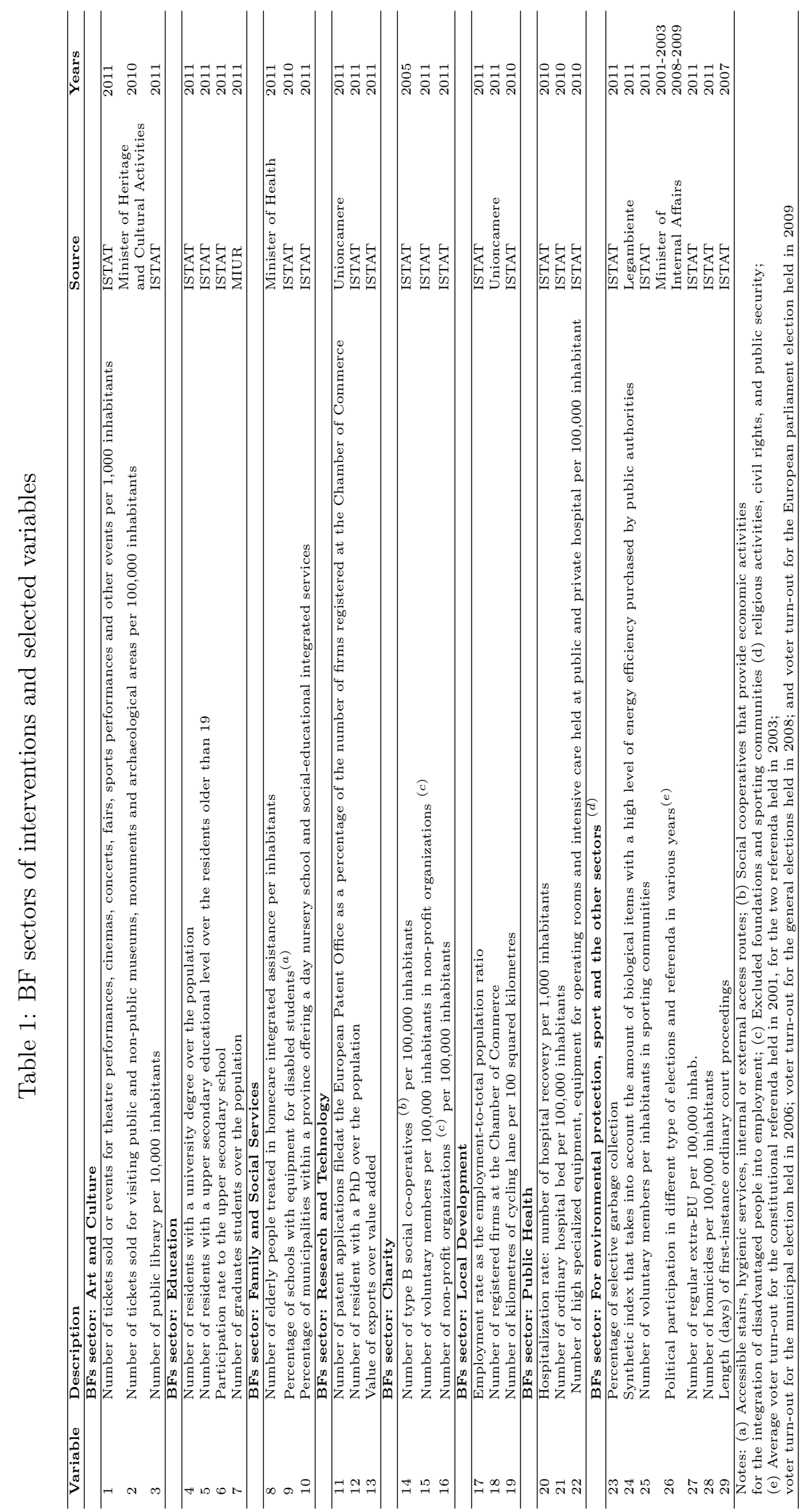




\section{An index of social capital for BFs}

The literature on social capital suffers from two main problems: the definition of social capital, which remains vague and hard to measure and, as a consequence, the disagreement that arises in interpreting which elements of social capital affect economic growth (Malecki, 2012). The lack of a common definition has given rise to different measures of social capital and a variety of applied empirical works. Generally, these studies start their analysis by classifying social capital into several main dimensions that are then reduced to a single index by means of the principal component analysis. ${ }^{13}$

The construction of our measure of social capital follows previous studies that adopt a multidimensional perspective. First, we select a set of variables that explicitly takes into account the BFs sectors of intervention, as discussed in Section 2. Second, for each sector of activity, we calculate one synthetic index by means of the Principal Component Analysis (Johnson and Wichern, 2002). ${ }^{14}$ Indeed, the PCA seeks to reduce the dimension of the data by finding few orthogonal linear combinations (the Principal Components, $\mathrm{PC}$ ) of the original variables with the largest variance. The first PC is the linear combination with the largest variance. The second $\mathrm{PC}$ is the linear combination with the second largest variance and orthogonal to the first PC, and so on. There are as many $\mathrm{PCs}$ as the number of the original variables.

In this paper we focus on the first PC as it explains most of the variance and shows significant correlations with all variables (see the next Section 3.1). Therefore, the rest of the PCs can be disregarded with minimal loss of information. Third, the eight indexes are aggregated in a synthetic weighted index of social capital by using the proportion of funds received on average by each sector over the 2001-2011. ${ }^{15}$ Finally, the social capital index is normalized to vary from 0 to 100 .

\subsection{PCA results}

PCA results are shown in Table 2. Columns (1) and (2) show the eigenvalues associated with the first two PCs for each of the eight sectors of intervention of BFs. The magnitude of the eigenvalues provides a measure of the original total variance explained and it is used to choose the number of PCs to retain. According to the so-called Kaiser rule, a PC should be retained if the corresponding eigenvalue is greater than 1, i.e., greater than the variance of a single standardized variable (Kaiser, 1970). In our analysis, all eigenvalues are greater than 1 for the first PC and smaller than 1 for the second PC, the only exception being the Education sector showing an eigenvalues of 1.06 (columns (1) and (2) respectively). ${ }^{16}$ As a result, we retained only the first PC for all sectors.

Columns (3) and (4) show the Accumulated Proportion of Variance (APV) explained by the first two PCs. If we focus on the first Principal Component (PC1), the Charity

\footnotetext{
${ }^{13}$ Attempts to draw a map of social capital for the Italian region or provinces are Rizzi and Popara (2006), Cartocci (2007), Micucci and Nuzzo (2005), Rizzi ( 2004), Righi and Turi (2007), and Righi (2013), Ferrara and Nisticò (2013). Fiorillo (2008) and Sabatini (2006) reviewed empirical contributions to the measurements of social capital.

${ }^{14}$ For comparative purposes the 29 variables of Table 1 have been standardized.

${ }^{15}$ The social capital index does not significantly change by calculating a simple instead of a weighted mean.

${ }^{16}$ In addition, to justify our selection choice we rely on the screen plot of the eigenvalue, which shows a distinct break on the second components.
} 
sector accounts for the highest proportion of the variance of the original data (71\%), while the Public Health sector the lowest (43\%).

Finally, columns (5) and (6) of Table 2 show two diagnostics tests. Column (5) shows the values of the Kaiser-Meyer-Olkin (KMO) statistic of sampling adequacy, that is a measure of the proportion of variance among variables that might be common variance. The lower the proportion, the more suited your data is to PCA. The test measures sampling adequacy for each variable in the model and for the complete model. KMO values between 0.8 and 1 indicate the sampling is adequate, while KMO values less than 0.6 indicate the sampling is not adequate (Kaiser, 1970). In this case remedial action should be taken either by deleting the offending variables or by including other variables related to the offenders. ${ }^{17}$ However, some authors set this lower-bound value at 0.5 (Cerny and Kaiser, 1977). In this case our PCA would pass the test of sampling adequacy, which is also confirmed by the Bartlett test of Sphericity shown in column (6). This test compares the correlation matrix to the identity matrix. Under the null hypothesis, the variables are not correlated, i.e., the correlation matrix is the same as the identity matrix, and the observed variables cannot be really transformed into linear combinations in a lower-dimensional space. Results shows that the null hypothesis of no correlation is rejected at $1 \%$ level of significance in all cases but in the Public Health sector for which the probability level is $10 \%$.

Table 2: Principal component analysis

\begin{tabular}{lcccccc}
\hline \multirow{2}{*}{ Sectors } & \multicolumn{1}{c}{$(1)$} & $(2)$ & \multicolumn{2}{c}{$(3)$} & $(4)$ & \multicolumn{2}{c}{$(5)$} & $(6)$ \\
& Eigenvalues & APV $(\%)$ & \multicolumn{2}{c}{ Test } \\
\hline Art and Culture & PC1 & PC2 & PC1 & PC2 & KMO & Bartlett \\
Education & 1.54 & 0.92 & 51.29 & 81.79 & 0.52 & $27.35^{* * *}$ \\
Family and Social Services & 2.19 & 1.06 & 54.77 & 81.30 & 0.56 & $154.26^{* * *}$ \\
Research and Technology & 1.68 & 0.87 & 55.99 & 85.02 & 0.53 & $43.70^{* * *}$ \\
Charity & 1.50 & 0.99 & 50.03 & 83.01 & 0.46 & $29.00^{* * *}$ \\
Local Development & 2.14 & 0.78 & 71.33 & 97.34 & 0.53 & $210.10^{* * *}$ \\
Public Health & 1.64 & 0.89 & 54.60 & 84.41 & 0.51 & $39.39^{* * *}$ \\
Environmental Protection & 1.30 & 0.94 & 43.26 & 74.53 & 0.53 & $7.53^{*}$ \\
\hline${ }^{* * *} p<0.01,{ }^{* *} p<0.05,{ }^{*} p<0.10$ & 3.43 & 0.89 & 49.07 & 61.79 & 0.81 & $233.84^{* * *}$ \\
\hline
\end{tabular}

Table 3 shows the loading factors, which measure the correlation between the original variables and the first two PCs. They measure how much of the variation in a single variable is explained by the component. Loading factors have the expected signs and, with few exceptions, show the highest values on the first retained PC. They suggest that $\mathrm{PC} 1$ is able to reduce the dimension of the original data by capturing most of the variation, with minimal loss of information for all the analyzed sectors.

The overall index of social capital obtained by means of the PCA is shown in Figure 3. As expected, social capital endowment is higher in Northern provinces and decreases as we move towards the Southern provinces. This geographical pattern also confirms previous findings such as Cartocci's (2007): the Spearman's rho correlation coefficient between the two indexes is 0.77 , implying that there is a tendency for provinces with

\footnotetext{
${ }^{17}$ Offending variables are those for which most of the zero-order correlations are negative.
} 
Table 3: Loading factors

\begin{tabular}{|c|c|c|c|}
\hline \multirow[t]{2}{*}{ Sectors } & \multirow[t]{2}{*}{ Variables } & \multicolumn{2}{|c|}{ Loading factors } \\
\hline & & PC1 & $\mathrm{PC} 2$ \\
\hline \multicolumn{4}{|c|}{ Art and Culture } \\
\hline & 1 Events & 0.603 & 0.738 \\
\hline & 2 Museums & 0.838 & -0.032 \\
\hline & 3 Public libraries & 0.687 & -0.608 \\
\hline \multicolumn{4}{|c|}{ Education } \\
\hline & 4 Graduate attainment & 0.801 & 0.523 \\
\hline & 5 High-school attainment & 0.906 & 0.296 \\
\hline & 6 High-school participation & 0.536 & -0.681 \\
\hline & 7 Graduate students & 0.664 & -0.486 \\
\hline \multicolumn{4}{|c|}{ Family and Social Services } \\
\hline & 8 Elderly people & 0.589 & 0.783 \\
\hline & 9 Equipped schools for disabled & 0.766 & -0.500 \\
\hline & 10 Nursery school & 0.864 & -0.090 \\
\hline \multicolumn{4}{|c|}{ Research and Technology } \\
\hline & 11 Patents & 0.862 & -0.006 \\
\hline & $12 \mathrm{PhD}$ attainment & 0.694 & -0.596 \\
\hline & 13 Export & 0.526 & 0.797 \\
\hline \multicolumn{4}{|c|}{ Charity } \\
\hline & 14 Social cooperatives & 0.595 & 0.803 \\
\hline & 15 Voluntary members & 0.931 & -0.310 \\
\hline & 16 Voluntary organization & 0.959 & -0.198 \\
\hline \multicolumn{4}{|c|}{ Local development } \\
\hline & 17 Employment & 0.863 & -0.026 \\
\hline & 18 Registered firm & 0.701 & -0.616 \\
\hline & 19 Cycling lane & 0.634 & 0.717 \\
\hline \multicolumn{4}{|c|}{ Public Health } \\
\hline & 20 Hospital recovery & 0.509 & -0.836 \\
\hline & 21 Bed in hospital & 0.688 & 0.471 \\
\hline & 22 Hospital equipment & 0.752 & 0.134 \\
\hline \multicolumn{4}{|c|}{ Environmental Protection } \\
\hline & 23 Selective garbage & 0.780 & 0.138 \\
\hline & 24 Biological items & 0.656 & -0.002 \\
\hline & 25 Voluntary members in sport & 0.781 & 0.061 \\
\hline & 26 Electoral turnout & 0.715 & 0.085 \\
\hline & 27 Regular immigrants & 0.757 & 0.365 \\
\hline & 28 Homicide & -0.470 & 0.842 \\
\hline & 29 Court proceedings & -0.694 & 0.136 \\
\hline
\end{tabular}


higher values in Cartocci's ranking to have also higher values in our ranking. ${ }^{18}$

Figure 3: Social capital index of BFs

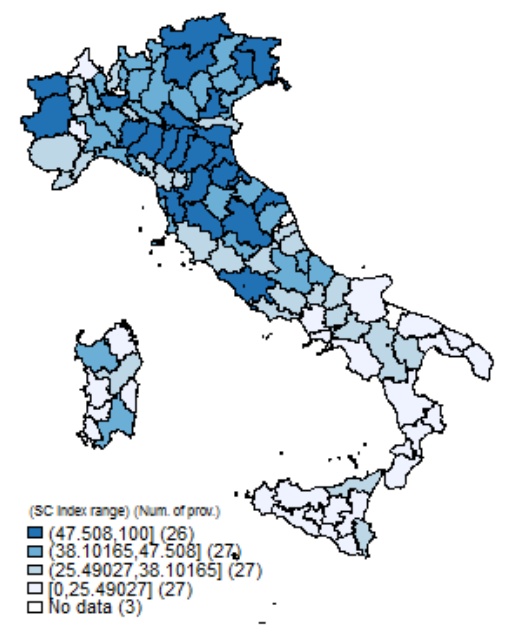

Finally, Figure 4 shows the social capital index (on the y-axis) versus the amount of BFs grants (Euro per million of Value Added, on the x-axis) observed in the year 2003, which is the beginning of the period in the empirical analyses of the next Section $4 .{ }^{19}$ This unconditional correlation suggests a non-linear (an inverted U-shaped) relationship between social capital and grants, with social capital increasing in grants up to certain levels of BFs grants, while decreasing afterwards. The following Section aims at investigating this apparently puzzling relationship that, as we will explain below, is partially due to incomplete information on grants, mainly of large-sized bank foundations.

\footnotetext{
${ }^{18}$ For robustness purposes, we calculated an additional social capital index using variables that capture those dimensions of social capital mostly shared by previous empirical contributions. These variables are: (1) political participation in different type of elections and referenda in various years; (2) the number of newspapers sold per inhabitants; (3) participation in non-profit organizations (number of voluntary members per inhabitants); (4) number of tickets sold or events for theatre performances, cinemas, concerts, fairs, sports performances and other events per inhabitants; (5) number of blood bags per million inhabitants collected by Avis, the Italian association of blood donors in $2002 ;(6)$ the number of homicides per inhabitants; (7) the length of first-instance ordinary court proceedings; (8) the percentage of selective garbage collection; (9) the percentage of schools with equipment for disabled students, such as accessible stairs, hygienic services, internal or external access routes; and (10) the number of patent applications filed at the European Patent Office as a percentage of the number of firms registered at provincial Chambers of Commerce. Apart from minor rank differences among provinces, results obtained by means of information from BFs are confirmed. The Spearman's rho correlation coefficient between this second social capital index and Cartocci's (2007) is 0.82. Data available upon request.

${ }^{19}$ In the regression samples the beginning of period refers to the year 2003 as data for per-capita expenditure for social security services, one of the explanatory variables, are not available at provincial level before this date.
} 
Figure 4: Social capital and BFs grants unconditional correlation in 2003

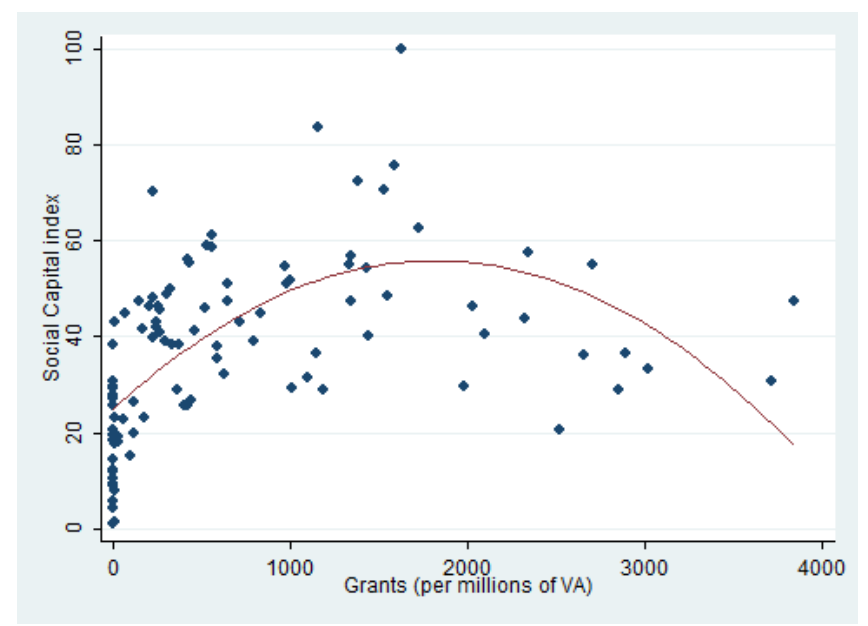

\section{$4 \quad$ BF grants, social capital and growth}

In this Section we present two empirical models to evaluate the impact of BFs activities on local economic development. The first model is used to test the impact of the grantmaking activities of BFs on social capital. To this purpose, we estimate a cross sectional model in which the dependent variable is the social capital index obtained in Section 3, and the independent variables are the BFs grants, together with other sources of local economic variables. The second model estimates the impact of BFs grant-making activity on provincial VA growth. Our hypothesis is that BFs funds, by increasing local social capital, have a positive impact on provincial economic growth.

\subsection{BFs grants and social capital}

The hypothesis that BFs sectoral grant-making activities contribute to build provincial social capital (SC hereinafter) endowments is at the basis of the SC index constructed in Section 3. In this Section we test whether social capital is directly affected by BFs grants, after adding other control variables to Model (1) as follows:

$$
S C_{i}=\alpha_{0}+\alpha_{1} \text { Grants }_{i}+\alpha_{2} \text { Grants }_{i}^{2}+\alpha_{3} \text { Cons }_{i}+\alpha_{4} \text { Loans }_{i}+\alpha_{5} \text { SocExp }_{i}+P_{i}+\epsilon_{i}
$$

where $i$ (for $i=1, \ldots, 102$ ) refers to provinces for which we have a complete dataset of observations. ${ }^{20}$ The dependent variable, $S C$ is our index of social capital. Grants is the provincial amount of BFs grants over Value Added, Cons is per-capita consumption, while Loans is the value of bank loans to the private sector as a share of VA. SocExp is the per-capita expenditure for social security services managed by municipalities, $P$

\footnotetext{
${ }^{20}$ In the year 2011 the number of provinces was 110. However, the provinces of Ogliastra, CarboniaIglesias, Medio Campidano, and Olbia-Tempio Pausania were created in 2006, while the provinces of Monza e della Brianza, Barletta-Andria-Trani, and Fermo in 2009. As a result, these 7 provinces are not included in the sample. Also, for statistical reason we have not included the province of Siena as indicated by the Walsh's non-parametric outlier test (Walsh, 1959).
} 
controls for fixed effects associated to the traditional sub-division of Italy in four macroareas. $^{21}$ We also add Grants $^{2}$ to capture the non-linearity in the relationship between the BFs' funds and social capital as discussed above (see Figure 4), while $\epsilon$ is an i.i.d. error term.

Most of the variables used in the construction of SC are measured in 2011 (see Table 1). To account for the potential effects of endogeneity the independent variables are measured as of 2003 , that is the first year data are available. ${ }^{22}$ Table 4 shows summary statistics, while Table 5 shows the correlation matrix among variables.

Table 4: Cross-section data descriptive statistics

\begin{tabular}{|c|c|c|c|c|c|c|}
\hline Variable & Unit of measure & Min & $\operatorname{Max}$ & Mean & Median & StDev \\
\hline $\mathrm{SC}$ & Index & 0 & 100 & 37.261 & 38.279 & 18.365 \\
\hline Grants & Euro per millions of VA & 0 & 3,842 & 742.798 & 382.212 & 907.790 \\
\hline Grants $^{2}$ & Euro per millions of VA & 0 & $14,764,654$ & $1,367,751$ & 146,270 & $2,745,698$ \\
\hline Cons & Thousands of Euro & 8.991 & 20.030 & 13.798 & 13.725 & 2.760 \\
\hline Loans & Euro per thousands of VA & 314.839 & 1,683 & 716.816 & 703.172 & 243.631 \\
\hline SocExp & Euro per capita & 12 & 395 & 91.441 & 81.000 & 60.032 \\
\hline Cartocci SC & Index & 0 & 100 & 54.016 & 59.496 & 26.114 \\
\hline
\end{tabular}

Table 5: Correlation matrix

\begin{tabular}{lllllll}
\hline & SC & Grants & Grants $^{2}$ & Cons & Loans & SocExp \\
\hline SC & 1 & & & & \\
Grants & $0.375^{* * *}$ & 1 & & & & \\
Grants $^{2}$ & $0.186^{*}$ & $0.935^{* * *}$ & 1 & & & \\
Cons & $0.709^{* * *}$ & $0.403^{* * *}$ & $0.203^{* *}$ & 1 & & \\
Loans & $0.711^{* * *}$ & $0.349^{* * *}$ & $0.235^{* * *}$ & $0.693^{* * *}$ & 1 & \\
SocExp & $0.576^{* * *}$ & $0.276^{* * *}$ & $0.147^{*}$ & $0.535^{* * *}$ & $0.412^{* * *}$ & 1 \\
\hline Notes: The number of observations is 102 for each variable. Grants, Cons, Loans \\
and SocExp refer to the year 2003; SC to 2011, while Cartocci CS to 2007. \\
${ }^{*} p<0.10,{ }^{* *} p<0.05,{ }^{* * *} p<0.01$ \\
\hline
\end{tabular}

Estimation results for Model (1) are shown in Table 6. OLS estimated coefficients are shown in column (1) and are all statistically significant, the only exception being the coefficient of Cons, and have the expected signs. Overall, there is evidence of a causal effect of local financing on social capital. Particularly, both bank loans, Loans, and public expenditure in local services, SocExp, have a positive effect on $S C$. As for the BFs grant-making activities, estimates confirm the positive effect of Grants on social capital, while the estimated negative coefficient of the squared term, Grants ${ }^{2}$, even though very small in size, also confirm the inverted U-shaped relationship between BFs grants and social capital of Figure 4. The estimated mean elasticity of social capital

\footnotetext{
21 The traditional four macro-areas are the North-West (with 24 provinces), North-East (with 22 provinces), Center (with 20 provinces), and the South (with 34 provinces).

${ }^{22}$ As discussed in Section 2 data on BFs grants are provided by ACRI. The other control variables are obtained from the Istat Territorial Indicators database, which contains main economic variables at provincial level. Variable definitions, data source and years are described in the Appendix.
} 
to BFs grants is $0.209 .{ }^{23}$ Thus, a $10 \%$ increase of Grants produces about a $2.1 \%$ increase of our social capital index.

Table 6: The impact of BFs grants on social capital: cross sectional model

\begin{tabular}{|c|c|c|c|c|}
\hline VARIABLES & $(1)$ & $(2)$ & $(3)$ & $(4)$ \\
\hline Grants & $\begin{array}{c}0.011^{* *} \\
(0.004)\end{array}$ & $\begin{array}{l}0.014^{*} \\
(0.008)\end{array}$ & $\begin{array}{c}0.007^{* *} \\
(0.003)\end{array}$ & $\begin{array}{c}0.009 * * * \\
(0.003)\end{array}$ \\
\hline Grants $^{2}$ & $\begin{array}{c}-0.000^{* * *} \\
(0.000)\end{array}$ & $\begin{array}{l}-0.000 \\
(0.000)\end{array}$ & & \\
\hline Cons & $\begin{array}{c}0.710 \\
(0.622)\end{array}$ & $\begin{array}{c}0.666 \\
(0.687)\end{array}$ & $\begin{array}{c}0.857 \\
(0.674)\end{array}$ & $\begin{array}{l}1.868^{*} \\
(1.059)\end{array}$ \\
\hline Loans & $\begin{array}{c}0.028^{* * *} * \\
(0.004)\end{array}$ & $\begin{array}{c}0.026^{* * *} \\
(0.004)\end{array}$ & $\begin{array}{c}0.027^{* * *} \\
(0.004)\end{array}$ & $\begin{array}{l}0.010 \\
(0.010)\end{array}$ \\
\hline SocExp & $\begin{array}{l}0.057^{*} \\
(0.032)\end{array}$ & $\begin{array}{c}0.053 \\
(0.034)\end{array}$ & $\begin{array}{l}0.055^{*} \\
(0.033)\end{array}$ & $\begin{array}{c}0.063^{* * *} \\
(0.020)\end{array}$ \\
\hline Constant & $\begin{array}{c}2.284 \\
(7.213)\end{array}$ & $\begin{array}{l}3.033 \\
(7.762)\end{array}$ & $\begin{array}{c}1.835 \\
(7.590)\end{array}$ & $\begin{array}{c}15.985 \\
(12.469)\end{array}$ \\
\hline Area dummy & Yes & Yes & Yes & Yes \\
\hline Province dummy* & No & Yes & Yes & Yes \\
\hline Observations & 102 & 102 & 102 & 102 \\
\hline R-squared & 0.702 & 0.746 & 0.743 & 0.802 \\
\hline AIC & 776.766 & 760.531 & 759.735 & 805.013 \\
\hline BIC & 800.391 & 784.155 & 780.735 & 826.013 \\
\hline Jarque-Bera test & $41642.844^{* * *}$ & $42071.361^{* * *}$ & $2596.393^{* * *}$ & $5163.967^{* * *}$ \\
\hline $\mathrm{SC} /$ Grants elasticities & 0.209 & 0.287 & 0.134 & 0.124 \\
\hline $\begin{array}{l}\text { Robust standard errors } \\
\text { *Provinces are: Asti B } \\
\text { Torino, Treviso, Venezi }\end{array}$ & $\begin{array}{l}\text { in parentheses } \\
\text { ella, Cuneo, Lu } \\
\text {, and Vibo Va }\end{array}$ & $\begin{array}{l}* * * \mathrm{p}<0.01,{ }^{* *} \\
\text { ca, Massa Carr } \\
\text { ntia. }\end{array}$ & $\begin{array}{l}\mathrm{p}<0.05,{ }^{*} \mathrm{p}< \\
\text { ra, Padova, } \mathrm{R}\end{array}$ & $\begin{array}{l}0.1 \\
\text { vigo, }\end{array}$ \\
\hline
\end{tabular}

The explanation for the non-linear relationship between Grants and $S C$ is likely due to the fact that BFs do not always provide a grant breakdown by province. In Section 2 we showed that, on average, during the 2001-2011 period almost $42 \%$ of the total BFs grants are distributed to provinces that are not those where the BFs are located. In the original dataset from ACRI grants are organized by BFs. To resume grants by province of destination we gathered information from each BFs' annual reports. Nevertheless, some grants could not be assigned to some of the provinces that effectively received the funds. Therefore, some provinces show an improper high level of the ratio between grants and VA to which does not correspond a proportional level of social capital. Another explanation, not necessarily alternative to the previous one, is that, as recently outlined in Ferri et al. (2015), BFs grant-making activities have large margins of improvements in terms of their effectiveness, which finds evidence in a nonlinear relationship between BFs size and their operational effectiveness.

As a robustness check for the solution to add Grants $^{2}$ to Model (1), we add dummy variables for those provinces above the 90th percentile of the Grants distribution. The

\footnotetext{
${ }^{23}$ This is computed combining the coefficient parameters of Grants and Grants ${ }^{2}$.
} 
ten provinces are Asti, Biella, Cuneo, Lucca, Massa Carrara, Padova, Rovigo, Torino, Treviso, and Venezia. ${ }^{24}$

Column (2) shows that, once Model (1) is augmented with the ten provincial dummies, the estimated coefficient of Grants ${ }^{2}$ is statistically not significant. This result clearly suggests that the squared of the BFs' grants and the ten dummy variables capture the measurement problems discussed above.

Column (3) shows the estimated coefficient of Model (1) with the provincial dummies, but without the squared term, which is also the best model specification according to the AIC and BIC tests shown at the bottom of Table 6. Still, the impact of BF grant-making activities on social capital is quantitative significant. Indeed, a $10 \%$ increase in Grants produces about a $1.34 \%$ increase in social capital, which suggests a key role for the BFs as source of local development.

Finally, for robustness purposes, column (4) of Table 6 shows OLS estimation results when using the social capital index by Cartocci (2007) as dependent variable. Estimates confirm previous findings of column (1), while the size of the estimated coefficient of Grants is larger and the corresponding elasticity lower than those obtained from the model specification of column (3). Furthermore, the estimated coefficient of per capita consumption is positive and statistically significant, indicating that social capital positively depends on measures of local wealth.

The diagnostic tests at the bottom of Table 6 suggest that the error terms are not normally distributed (the Jarque-Bera test rejects the null hypothesis of normality in all cases). Thus, to overcome this problem, we also estimate the Model (1) by quantile regression (Koenker and Bassett, 1978) that, differently from OLS estimation method, requires no specific assumption about the distribution of the error term. Further, quantile regression models allows to analyze how social capital responds to changes in the regressors at various percentiles of the conditional distribution of $S C$.

Table 7 shows estimation results from quantile regression models in columns (2) to (5). For comparative purposes, column (1) also shows OLS estimates of column (3) of Table 6. In all cases, the estimated coefficients are statistically significant and have the expected signs. Furthermore, differently from the OLS results, the estimated coefficient of per capita consumption is positive and statistically significant in columns (3) and (4). Interestingly, the quantile regression estimates imply that the elasticity of $S C$ to Grants is the largest (0.230) at the 90th percentile of the social capital distribution (column (5) of Table 7). It suggests that the contribution of BFs grants to build social capital is more effective in provinces with higher social capital endowment than in provinces endowed with lower social capital.

\subsection{BFs grants and income growth}

In this Section we aim at testing whether BFs funds also affect local growth besides social capital. Indeed, Peiró-Palonimo and Tortosa-Ausina (2015) and Peiró-Palonimo (2016) show that social capital has a positive impact on GDP per-capita growth and that this effect may be nonlinear. As previously stated at the beginning of the paper, our hypothesis is that BFs grants affect local economic growth through the creation of more social capital.

\footnotetext{
${ }^{24}$ We also add the dummy for Vibo Valentia, which is the province with CS index equals to 0.
} 
Table 7: The impact of BFs grants on social capital: quantile model

\begin{tabular}{|c|c|c|c|c|c|}
\hline & (1) & (2) & (3) & $(4)$ & $(5)$ \\
\hline VARIABLES & OLS & .25 & .50 & .75 & .90 \\
\hline Grants & $\begin{array}{c}0.007^{* *} \\
(0.003)\end{array}$ & $\begin{array}{c}0.005^{* * *} \\
(0.000)\end{array}$ & $\begin{array}{c}0.004^{* * *} \\
(0.000)\end{array}$ & $\begin{array}{c}0.005^{* * *} \\
(0.000)\end{array}$ & $\begin{array}{c}0.015^{* *} \\
(0.006)\end{array}$ \\
\hline Cons & $\begin{array}{c}0.857 \\
(0.674)\end{array}$ & $\begin{array}{c}1.142 \\
(0.000)\end{array}$ & $\begin{array}{c}0.589^{* * *} \\
(0.000)\end{array}$ & $\begin{array}{c}0.087^{* * *} * \\
(0.000)\end{array}$ & $\begin{array}{c}0.317 \\
(2.338)\end{array}$ \\
\hline Loans & $\begin{array}{c}0.027^{* * *} \\
(0.004)\end{array}$ & $\begin{array}{c}0.023^{* * *} \\
(0.000)\end{array}$ & $\begin{array}{c}0.029^{* * *} * \\
(0.000)\end{array}$ & $\begin{array}{c}0.034^{* * *} \\
(0.000)\end{array}$ & $\begin{array}{c}0.026 \\
(0.026)\end{array}$ \\
\hline SocExp & $\begin{array}{l}0.055^{*} \\
(0.033)\end{array}$ & $\begin{array}{c}0.031^{* * *} \\
(0.000)\end{array}$ & $\begin{array}{c}0.031^{* * *} \\
(0.000)\end{array}$ & $\begin{array}{c}0.050^{* * *} \\
(0.000)\end{array}$ & $\begin{array}{c}0.158 \\
(0.122)\end{array}$ \\
\hline Constant & $\begin{array}{c}1.835 \\
(7.590)\end{array}$ & $\begin{array}{l}-2.480 \\
(0.000)\end{array}$ & $\begin{array}{c}5.324 \\
(0.000)\end{array}$ & $\begin{array}{l}15.524 \\
(0.000)\end{array}$ & $\begin{array}{c}7.404 \\
(23.458)\end{array}$ \\
\hline Area dummy & Yes & Yes & Yes & Yes & Yes \\
\hline Province dummy* & Yes & Yes & Yes & Yes & Yes \\
\hline Observations & 102 & 102 & 102 & 102 & 102 \\
\hline R-squared (pseudo) & 0.743 & 0.573 & 0.545 & 0.510 & 0.562 \\
\hline $\mathrm{SC} /$ Grants elasticities & 0.134 & 0.107 & 0.090 & 0.094 & 0.230 \\
\hline $\begin{array}{l}\text { Robust standard errors } \\
\text { *Provinces are: Asti B } \\
\text { Torino, Treviso, Venezi }\end{array}$ & parent & $\begin{array}{l}\text { S- } * * * \\
\text { ucca, } \\
\text { uct }\end{array}$ & $.01, * *$ & $.05, * 1$ & $\begin{array}{l}.1 \\
\text { vigo, }\end{array}$ \\
\hline
\end{tabular}

We follow the common approach used in the empirical literature and assume that all provinces share the same initial conditions in the growth process (Islam 2003). Thus, in an unconditional specification, the annual growth rate of the per-capita value added is regressed on just its initial level:

$$
V \dot{A}_{i t}=\ln V A_{i t}-\ln V A_{i t-1}=\gamma_{1} \ln V A_{i t-1}+\eta_{t}+\nu_{i t}
$$

where $V \dot{A}_{i t}$ is the per-capita VA in province $i$ at time $t$ and $\gamma_{1}=-\left(1-e^{-\beta t}\right) .{ }^{25}$ The above specification allows the regressors to vary both across provinces $i$ and over time $t$. Also, $\eta_{t}$ is a time-specific effect, which aims at capturing the effect of business cycle fluctuations, and $\nu_{i t}$ is the error term.

Although the assumption that different provinces may converge to the same steadystate, that is, they share the same deep determinants, is in general plausible within a country, it might not apply to Italy, as regions/provinces are so different in geography, institutions and local policies. So we present a conditional model, and check if BFs grants and social capital have a positive impact on income growth, once controlled for provincial characteristics. ${ }^{26}$

Ideally, the baseline model specification would allow provincial economic growth to be dependent of social capital, which should enter directly into the above unconditional

\footnotetext{
${ }^{25}$ From the estimated $\gamma_{1}$ coefficient it is possible to recover the speed of convergence according to the formula: $\beta=-\frac{\ln \left(1+\gamma_{1}\right)}{T}$

${ }^{26}$ Choices concerning which variables are deep determinants of growth vary greatly; examples are indicators of human capital, trade openness, institutional or geographical variables (Durlauf et al. 2005).
} 
model specification toghether with other controls. However, our social capital index is only available for the year 2011. To get around the lack of time series on social capital, (2) is augmented with the explanatory variables of Model (1) as follows:

$$
\begin{aligned}
V \dot{A}_{i t} & =\gamma_{0}+\gamma_{1} \ln V A_{i t-1}+\gamma_{2} \text { Grants }_{i t-1}+\gamma_{3} \text { Grants }_{i t-1}^{2}+\gamma_{4} \text { Cons }_{i t-1}+ \\
& +\gamma_{5} \text { Loans }_{i t-1}+\gamma_{6} \text { SocExp }_{i t-1}+\eta_{t}+\nu_{i t}
\end{aligned}
$$

Having data on the time and space dimensions for all variables, Model (3) can be written as a simple panel equation predicting the provincial VA growth rates. ${ }^{27}$

Data are from 2003 to 2011 and the number of provinces is $100 .{ }^{28}$ To control for possible nonlinearities due to measurement issues or the presence of inefficiencies, as discussed in the previous Section, we also include the squared term of grants, Grants ${ }^{2}$, among the regressors. ${ }^{29}$ In the Appendix, Table A1 and Table A2 show descriptive statistics and variable definitions, respectively.

Table 8 shows estimation results of Model (3). For comparative purposes, column (1) shows the estimated coefficients of the unconditional convergence Model (2), while column (2) displays the conditional least-squares estimations of Model (3), respectively. Results from the Fixed-effects estimator are shown in column (3). The conditional OLS and the FE estimations provide the upper and the lower bounds for the autoregressive coefficient on per-capita VA.

Column (4) shows the one-step GMM system results. In this case, we take into account the dynamic nature of our data, and use all lagged levels of the dependent variable as instruments for the equation in difference, and all lagged differences of the dependent variable as instruments for the equation in levels (Blundell and Bond 1998). ${ }^{30}$

Estimated coefficients are all statistically significant, except for the squared term of grants, Grants ${ }^{2}$, and for the public spending in social security services, SocExp, which instead was found to be determinant of social capital in Section 4.1. The estimated coefficient of the lagged per-capita VA is equal to -0.172 , indicating an annual speed of

\footnotetext{
${ }^{27}$ There are several advantages of panel data over cross-sectional or time-series data such as the fact that they usually contain more degrees of freedom and more sample variability than cross-sectional data, hence improving the efficiency of econometric estimates, or that they have greater capacity for capturing the complexity of local economies than a single cross-section or time series data (for instance, panel data may allow one to control the effects of missing or unobserved variables). A longer lists of advantages of panel data over cross-sectional or time-series data may be found in Hsiao (2003).

${ }^{28}$ Besides Siena, which was dropped in the cross-section model of Section 4.1, we did not retain the provinces of Nuoro and Siracusa. According to the Walsh's test these are both outliers, as they report extreme values for degree of openness to international trade (Tradeop), and the number of homicide (Homic) respectively, which are two regressors added to Model (3) (see Table 8 in Column (5) and Column (6)). For comparison reasons we kept the number of observations to 100 in all the models reported in Table 8.

${ }^{29}$ In this panel specification Grants is the ratio between BFs grants and VA in each year, while the other regressors have the same usual meaning. Differently from the cross-section model estimated in Section 4.1, in which province dummies were included to control for measurement problems related to the BFs' grant-making activities, Model 3 has among the regressors the variable Grants ${ }^{2}$. Having checked that the two alternatives produce equivalent results, the choice to include Grants ${ }^{2}$ instead of the dummy variables depends on the fact that the latter conflict with the time dummies. Also, area dummies are not included to allow for greater variability in the time dimension of the data.

${ }^{30}$ We opted to estimate Model 3 by means of GMM-system to overcome a potential small-sample bias due to the limited number of time periods and a dependent variable with a high degree of persistence.
} 
Table 8: The impact of BFs grants on economic growth: panel data model (2003-2011)

\begin{tabular}{|c|c|c|c|c|c|c|}
\hline VARIABLES & $\begin{array}{c}(1) \\
\text { OLS }\end{array}$ & $\begin{array}{c}(2) \\
\text { OLS }\end{array}$ & $\begin{array}{l}(3) \\
\text { FE }\end{array}$ & $\begin{array}{c}(4) \\
\text { GMM-sys }\end{array}$ & $\begin{array}{c}(5) \\
\text { GMM-sys }\end{array}$ & $\begin{array}{c}(6) \\
\text { GMM-sys }\end{array}$ \\
\hline $\ln \mathrm{VA}_{t-1}$ & $\begin{array}{c}-0.008^{* * *} \\
(0.002)\end{array}$ & $\begin{array}{c}-0.157^{* *} \\
(0.063)\end{array}$ & $\begin{array}{c}-0.533^{* * *} \\
(0.050)\end{array}$ & $\begin{array}{c}-0.172^{* * *} \\
(0.033)\end{array}$ & $\begin{array}{c}-0.164^{* * *} \\
(0.026)\end{array}$ & $\begin{array}{c}-0.158^{* * *} \\
(0.026)\end{array}$ \\
\hline Grants $_{t-1}$ & & $\begin{array}{l}0.011^{*} \\
(0.006)\end{array}$ & $\begin{array}{l}-0.005 \\
(0.006)\end{array}$ & $\begin{array}{l}0.012^{*} \\
(0.006)\end{array}$ & $\begin{array}{c}0.014^{* *} \\
(0.005)\end{array}$ & $\begin{array}{l}0.005^{*} \\
(0.003)\end{array}$ \\
\hline $\operatorname{Grants}^{2}{ }_{t-1}$ & & $\begin{array}{l}-0.002 \\
(0.001)\end{array}$ & $\begin{array}{c}0.000 \\
(0.001)\end{array}$ & $\begin{array}{l}-0.002 \\
(0.001)\end{array}$ & $\begin{array}{c}-0.003^{* *} \\
(0.001)\end{array}$ & \\
\hline Loans $_{t-1}$ & & $\begin{array}{c}0.040^{* *} \\
(0.018)\end{array}$ & $\begin{array}{l}-0.015 \\
(0.025)\end{array}$ & $\begin{array}{c}0.048^{* * *} \\
(0.012)\end{array}$ & $\begin{array}{c}0.024^{* *} \\
(0.011)\end{array}$ & $\begin{array}{c}0.023^{* *} \\
(0.011)\end{array}$ \\
\hline $\operatorname{SocExp}_{t-1}$ & & $\begin{array}{c}0.051 \\
(0.038)\end{array}$ & $\begin{array}{c}0.018 \\
(0.061)\end{array}$ & $\begin{array}{c}0.057 \\
(0.036)\end{array}$ & $\begin{array}{c}0.019 \\
(0.030)\end{array}$ & $\begin{array}{c}0.022 \\
(0.029)\end{array}$ \\
\hline Cons $_{t-1}$ & & $\begin{array}{c}0.007^{* *} \\
(0.003)\end{array}$ & & $\begin{array}{c}0.007^{* * *} \\
(0.002)\end{array}$ & $\begin{array}{c}0.006^{* * *} \\
(0.002)\end{array}$ & $\begin{array}{c}0.007^{* * *} * \\
(0.002)\end{array}$ \\
\hline $\operatorname{Tradeop}_{t-1}$ & & & & & $\begin{array}{c}0.046^{* * *} \\
(0.016)\end{array}$ & $\begin{array}{c}0.043^{* * *} \\
(0.016)\end{array}$ \\
\hline $\operatorname{Grad}_{t-1}$ & & & & & $\begin{array}{l}-0.007 \\
(0.027)\end{array}$ & $\begin{array}{l}-0.005 \\
(0.026)\end{array}$ \\
\hline Homic $_{t-1}$ & & & & & $\begin{array}{c}-0.006^{* * *} \\
(0.002)\end{array}$ & $\begin{array}{c}-0.005 * * * \\
(0.002)\end{array}$ \\
\hline $\operatorname{Tour}_{t-1}$ & & & & & $\begin{array}{c}0.030 \\
(0.134)\end{array}$ & $\begin{array}{c}0.013 \\
(0.150)\end{array}$ \\
\hline Constant & $\begin{array}{c}0.049 * * \\
(0.024)\end{array}$ & $\begin{array}{c}1.344^{* *} \\
(0.548)\end{array}$ & & $\begin{array}{c}1.474^{* * *} \\
(0.286)\end{array}$ & $\begin{array}{c}1.479^{* * *} \\
(0.233)\end{array}$ & $\begin{array}{c}1.414^{* * *} \\
(0.224)\end{array}$ \\
\hline Time Dummy & Yes & Yes & Yes & Yes & Yes & Yes \\
\hline Province Dummy* & No & No & No & No & No & Yes \\
\hline Observations & 1,000 & 800 & 800 & 800 & 700 & 700 \\
\hline Number of provinces & 100 & 100 & 100 & 100 & 100 & 100 \\
\hline Number of instruments & 11 & 18 & 14 & 75 & 71 & 80 \\
\hline $\operatorname{AR}(1)$ & 0.100 & 0.082 & 0.156 & 0.000 & 0.000 & 0.000 \\
\hline $\operatorname{AR}(2)$ & 0.047 & 0.063 & 0.001 & 0.955 & 0.521 & 0.593 \\
\hline Hansen Test & & & & 0.150 & 0.131 & 0.317 \\
\hline $\begin{array}{l}\text { Robust standard errors } \\
{ }^{*} \text { Provinces are: Asti Bie } \\
\text { Torino, Treviso, Venezia }\end{array}$ & $\begin{array}{l}\text { arenthes } \\
\text { Cuneo, } \\
\text { d Vibo }\end{array}$ & $\begin{array}{l}-* * * \mathrm{p} \\
\text { cca, } \mathrm{Ma} \\
\text { lentia. }\end{array}$ & $\begin{array}{l}01,{ }^{* *} \mathrm{p} \\
\text { Carrara }\end{array}$ & $\begin{array}{l}5,{ }^{*} \mathrm{p}<0 \\
\text { dova, } \mathrm{Ro}\end{array}$ & & \\
\hline
\end{tabular}


convergence of around $1.9 \%$ and a half-life of around 37 years. ${ }^{31}$ These results suggest that a slow convergence process is taking place among Italian provinces. Finally, the estimated coefficient of BFs grants is positive and statistically significant, supporting our hypothesis that bank foundations play an important role in enhancing the economic growth of Italian provinces.

The bottom of Table 8 shows diagnostic tests that the GMM-system estimates are properly specified (Blundell and Bond, 1998): the p-values for first $(\operatorname{AR}(1))$ and second order $(\operatorname{AR}(2))$ autocorrelated disturbances in the first-differenced equation show high first order autocorrelation, while there is no evidence for significant second order autocorrelation. Further, the reported p-value for Hansen J-test suggests that we fail to reject the null hypothesis of the validity of the overidentifying restrictions.

The last two specifications of Model (3) shown in column (5) and (6) include among the regressors some other variables that the empirical literature found as growth determinants in the convergence process among Italian regions or provinces.

The first of these new variables additional is the degree of openness to international trade (Tradeop). Vaona (2008) shows that this variable, measured as the sum of export and imports over VA, positively affects local development. The second variable is the number of undergraduate and graduate students as a share of the population (Grad). It controls the level of human capital that in the economic development literature has been widely recognized as an important determinant of growth. ${ }^{32}$ Hirsch and Sulis (2009) and Di Liberto (2008) find that, in the case of the Italian regions, human capital endowments and accumulation are both important determinants of regional growth. The third variable is the number of homicide per 100,000 inhabitants (Homic), to proxy for criminal activity. Indeed, previous empirical analyses find that crime has a negative effect on the value added of Italian provinces (Carboni e Detotto 2016; Mauro and Carmeci 2007), or that crime could represent a major hurdle to industrial development for some provinces (Peri 2004). We also control for the number of tourist arrivals in accommodations (Tour) as a proxy for the role of tourism in provincial economies. The choice of (Tour) is motivated by the fact that the tourism industry accounts for a significant share of GDP and employs a substantial proportion of the labour force in Italy. ${ }^{33}$ Cortés-Jiménez (2006) and Marrocu and Paci (2012) show that tourism has a positive effect on local GDP.

Finally, in column (5) we include the squared terms of Grants among the regressors, while in column (6) this variable is replaced with the province dummies, after having checked that the two alternatives produce equivalent results in the previous Section 4.1.

Overall, estimated coefficients in column (5) and in column (6) of Table 8 confirm findings of column (4). ${ }^{34}$ The estimated coefficient of lagged per-capita VA is equal to -0.164 and to -0.158 respectively, with a resulting speed of convergence of about $1.8 \%$ and $1.7 \%$, and a half-life of around 39 and 41 years. More importantly, BFs grants continue to show a positive effect on growth, thus confirming the important role of bank

\footnotetext{
${ }^{31}$ The implied half-life is defined as the time necessary for a province to reduce the gap between per-capita income and its steady state value by one half and it is given by: $\tau=-\frac{\ln (2)}{\ln (1+\gamma)}$.

${ }^{32}$ See Lodde (2008) for a review of empirical studies on the relationship between human capital and growth.

${ }^{33}$ According to the World Travel and Tourism Council (2012) the tourism industry account for $4.1 \%$ of GDP in 2012 and $4.6 \%$ of the total employment.

${ }^{34}$ The number of observations used to estimate model specifications (5) and (6) is 700 as data for Tour are available until 2009.
} 
foundation activities on local development. Based on the estimated coefficient of Grants of column (6), the implied mean elasticity of the VA growth rate to Grants is equal to 0.05. Thus, a 10\% increase in Grants increases the VA growth rate of $0.5 \%$. While the estimated mean elasticity seems quantitatively not very large, it should be kept in mind that the 2003-2011 mean value of BF grants over Value Added is only 0.89 cents per thousands euros (see Table A1).

Finally, while there is no evidence of a significant role of human capital or tourism activity on local growth, trade openness and criminal activities seem to be, respectively, relevant positive and negative determinants of provincial economic growth.

\section{Conclusions}

The Italian economic dualism has historically referred to the considerable disparities in terms of GDP per capita and growth patterns among the Northern and Southern Italian regions and provinces. Although differences started to decline significantly since the beginning of the 60's to the earlier years of the 70's, there is a general consensus that convergence came to a halt in the subsequent decades. Although several factors contribute to explaining differences in growth and convergence patterns among provinces, starting from the pioneering work of Putnam (1993) social capital has been considered as one key element in determining the Italian economic dualisms. In this paper we focus on the role of BFs in determining social capital and, in turn, economic growth. As mentioned throughout the study, our starting hypothesis is that BFs exert a positive impact on social capital by means of their socially oriented activities. Thus, our analysis started by analyzing the activities undertaken by BFs and collecting data on Italian BFs grants and projects funded. Thus, by means of PCA we obtained a measure of social capital for Italian provinces, which takes into account the sectors of intervention of BFs. Then, we investigated whether social capital was actually affected by BFs grants, controlling for other measures of local financing. According to our results, social capital is positively influenced by BFs grants, corroborating the importance of bank foundations activities for sectors that are at the core of social capital.

In turn, this finding support the idea that BFs by increasing social capital have a positive impact on economic growth at the provincial level. In terms of policy implications, our results suggest that policies should aim to reinforce and stimulate BFs activities, and in turn to generate greater endowments of social capital in the more fragile Italian provinces. 


\section{A Appendix}

Table A1: Panel data descriptive statistics

\begin{tabular}{llrrrrrr}
\hline variable & Unit of measure & N & min & max & mean & p50 & sd \\
\hline lnVA & Euro (log) & 700 & 9.194 & 10.316 & 9.793 & 9.869 & 0.255 \\
Grants & Euro per thousands of VA & 700 & 0.000 & 5.055 & 0.885 & 0.494 & 1.050 \\
Loans & Euro per VA & 700 & 0.343 & 2.203 & 0.856 & 0.826 & 0.289 \\
SocExp & Euro per thousands of VA & 700 & 0.007 & 0.359 & 0.103 & 0.095 & 0.056 \\
Cons & Thousands of Euro & 700 & 9.216 & 22.052 & 15.140 & 15.150 & 2.966 \\
Tradeop & Euro per VA & 700 & 0.014 & 1.178 & 0.405 & 0.401 & 0.243 \\
Grad & Per thousands of inhabitants & 700 & 0.215 & 0.876 & 0.484 & 0.461 & 0.106 \\
Homic & Per 100,000 inhabitants & 700 & 0.000 & 7.142 & 0.943 & 0.701 & 1.021 \\
Tour & Per 100 inhabitants & 700 & 0.002 & 0.111 & 0.016 & 0.010 & 0.018 \\
\hline
\end{tabular}




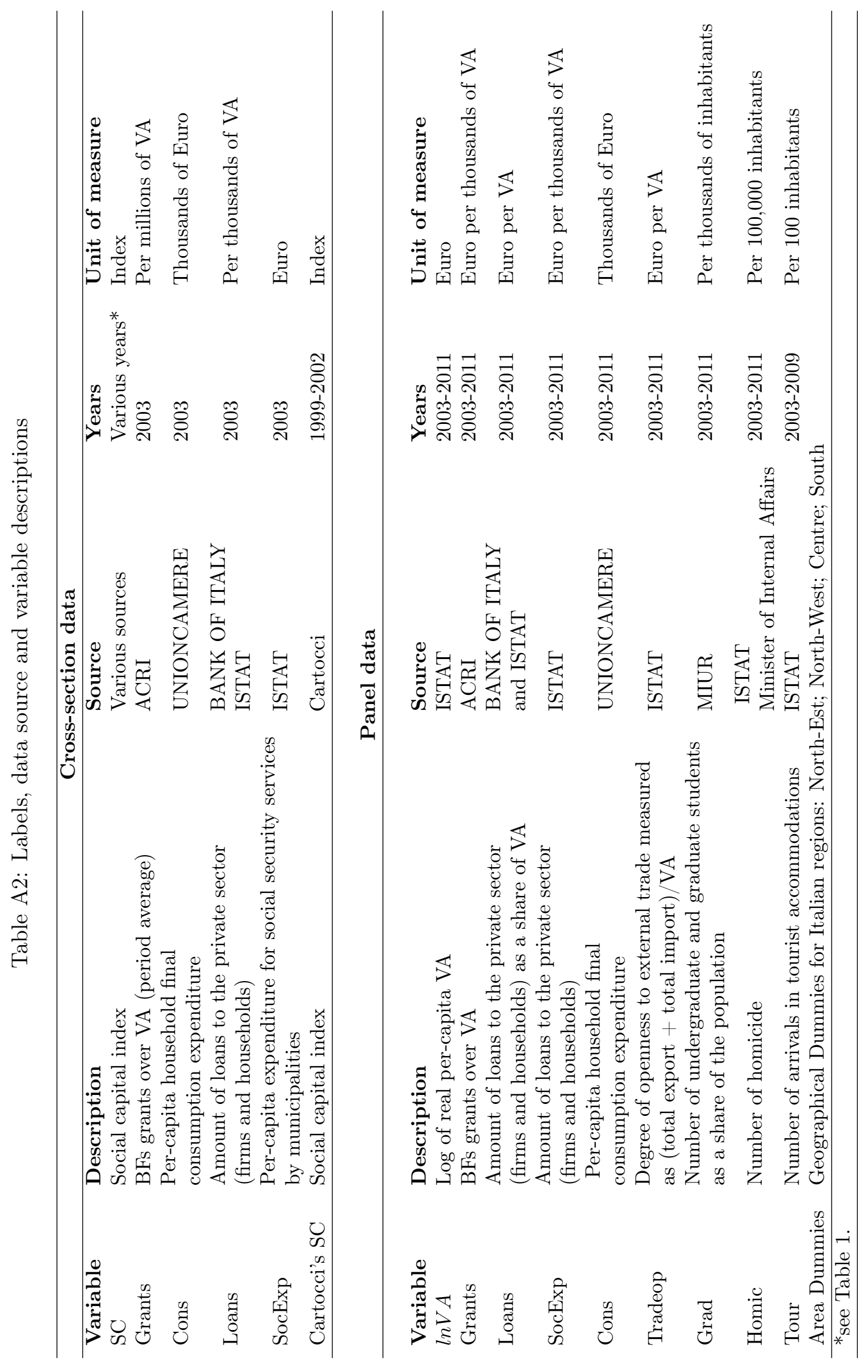




\section{B References}

ACRI (2011), Diciottesimo rapporto sulle Fondazioni di origine bancaria, Rome.

Akcomak, S. and Ter Weel, B., (2009) Social capital, innovation and growth: evidence from Europe, European Economic Review, 53 (5): 544-67.

Andriani L. and Karyampas D., (2009) A New Proxy of Social Capital and the Economic Performance across the Italian Regions, Birkbeck Working Papers in Economics and Finance, London.

Arbia G., Basile R., and Mirella S., (2002) Regional Convergence in Italy 1951-199: A Spatial Econometric Perspective, ISAE Working Papers 29, ISAE- Rome.

Arellano, M. and S. Bond (1991): Some Tests of Specification for Panel Data: Monte Carlo Evidence and an Application to Employment Equations, Review of Economic Studies , 58, 277-297

Arrighetti, A. and Lasagni, A., (2010) Capitale Sociale, Contesto Istituzionale e Performance Innovative delle Imprese, Scienze Regionali, 10: 5-34.

Bandera L. (2013) Le Fondazioni di origine bancaria: sperimentazione e sostegno alle reti, in F. Maino e M. Ferrera (eds), Primo rapporto sul secondo welfare in Italia 2013, Torino, Centro di Ricerca e Documentazione Luigi Einaudi.

Barbetta G.P. 2002 Il ruolo delle fondazioni bancarie nel finanziamento delle imprese sociali attive nei settori dei servizi sociali e della sanità, in Modelli di governo, riforma dello stato sociale e ruolo del terzo settore, 341-359, Il Mulino, Bologna

Barbetta G.P. (2013) Le Fondazioni, Il Mulino Bologna

Barone G., and de Blasio G. (2013) Electoral Rules and Voter Turnout, International Review of Law and Economics, 36, 25-35.

Beugelsdijk S., and Van Schaik T. (2005) Differences in social capital between 54 Western European regions, Regional Studies, 39 (8), 1053-1064.

Blundell, R., and S. Bond (1998), Initial Conditions and Moment Restrictions in Dynamic Panel Data Models, Journal of Econometrics, 87, 115-143

Buonanno, P., Montolio, D., and Vanin, P. (2009) Does social capital reduce crime? Journal of Law and Economics, 52(1), 145-170.

Cainelli, G., Mancinelli, S. and Mazzanti, M. (2005) Social capital, R\&D and industrial District, Feem Working papers n. 744584.

Camagni R. (2008) Regional Competitiveness: Towards a Concept of territorial capital, in Capello R., Camagni R., Chizzolini B. and Fratesi U. (eds.), Modelling Regional Scenarios for the Enlarged Europe: European Competitiveness and Global Strategies, p. 33-48, Springer Verlag, Berlin.

Carboni, O.A., and Detotto, C. (2016) The economic consequences of crime in Italy, Journal of Economic Studies, 43, 122-40

Cartocci, R.(2007) Mappe del Tesoro. Atlante del capitale sociale in Italia. Bologna: Il Mulino.

Cerny, C.A. and Kaiser, H.F. (1977) A study of a measure of sampling adequacy for factor-analytic correlation matrices. Multivariate Behavioral Research, 12(1), 43-47.

Cliff A.D. and J. K. Ord (1973), Spatial autocorrelation, Pion, London.

Cooke P., Clifton N., and Oleaga M. (2005) Social capital, firm embeddedness and regional development, Regional Studies, 39 (8), 1065-1077.

Cortés-Jiménez, I., (2006) Which type of tourism matters to the regional economic growth? The cases of Spain and Italy, International Journal of Tourism Research, 10, 
127-39.

Crescenzi, R., Gagliardi, L., and Percoco, M., (2013) The bright side of social capital: how 'bridging' makes Italian provinces more innovative, in Crescenzi, R. and Percoco, M. (eds.) Geography, Institutions and Regional Economic Performance, Advances in Spatial Science series, 143-164. DOI: 10.1007/978-3-642-33395-8-8

De Blasio, G., and Nuzzo, G. (2006) The legacy of history for development: The case of Putnam's social capital. Bank of Italy Temi di Discussione.

De Blasio, G., and Nuzzo, G. (2010) The individual determinants of social behavior. Journal of Socio-Economics, 39(4),466-473.

De Blasio, G., and Nuzzo, G. (2012) Capitale sociale e disuguaglianza in Italia, Questioni di Economia e Finanza, Bank of Italy, n.116.

Dee, T.S. (2004), Are there civic Returns to education?, Journal of Public Economics, 88, 1697-1720.

Del Monte A., and Papagni E. (2007) The determinants of corruption in Italy: Regional panel data analysis, European Journal of Political Economy 23(2), 379-396.

Di Lascio, V., and G. Segre (2008) Il contributo delle fondazioni di origine bancaria alla spesa delle amministrazioni locali per la cultura e i beni culturali, in La finanza locale in Italia. Rapporto 2007, 210-224. FrancoAngeli.

Di Liberto, A. (2008) Education and Italian Regional Development, Economics of Education Review, 27, 94-107.

Durlauf, S. N., P. A. Johnson and J. R. W. Temple (2005), Growth Econometrics, in S.N. Durlauf and P. Aghion (Eds.), Handbook of Economic Growth, Elsevier

Ferrante, F., and Sabatini F., (2007) Education, Social Capital and Entrepreneurial Selection in Italy, MPRA WP. 2451.

Ferrara A. R., and Nistico' R. (2013) Well-being indicators and convergence across Italian regions, Applied Research in Quality of Life, 8(1), 15-44.

Ferri, G., M. Intonti, C. Cinzia, I. Cosmai (2015), L'Efficacia Operativa Delle Fondazioni Di Origine Bancaria Italiane: Un'Analisi Empirica, Euricse Working Papers, 79 .

Filtri A., Guglielmi A., Italian Banking Foundation, Milan, Mediobanca ecurities, 2012.

Fine, B. (2001) Social capital versus Social Theory. Political economy and social science at the turn of the millennium, Routledge London

Fiorillo D. ,(2008) Le determinanti del capitale sociale in Italia, Rivista Italiana degli Economisti, 13, 81-135.

Funari S., and RizziI D. (2003), Una valutazione della capacità di erogazione delle fondazioni bancarie del Nord-Est, Economia Pubblica, 4, 89-115.

Guiso, L., Sapienza, P., and Zingales, L. (2004). The role of social capital in financial development, American Economic Review, 94(3), 526-556.

Hauser, C., Tappeiner, G. and Walde, J., (2007). The Leaning Region: The Impact of Social Capital and weak Ties on Innovation, Regional Studies 41 (1): 75-88.

Hirsch, C., and Sulis G. (2009) Schooling, Production Structure and Growth: An Empirical Analysis on Italian Regions, Rivista Italiana degli Economisti, 14(3), 395-419.

Hsiao, C., (2003), Analysis of Panel Data, second edition, Cambridge University Press.

Irpet, (2011), L'impatto economico sul territorio dei progetti dell'ente Cassa di Risparmio di Firenze anni 2008-2011. 
Islam, N., (2003) What have we learnt from the convergence debate?, Journal of Economic Survey, 17, 309-362.

Iyer S., Kitson M. and Toh B., (2005) Social capital, economic growth and regional development, Regional Studies, 39 (8): pp.1015-1040.

Johnson, R. A., and Wichern, D. W. (2002) Applied Multivariate Statistical Analysis, Prentice Hall, Englewood Cliffs, NJ.

Jordan, J.L.., Anil, B., Munasib, A. (2010) Community Development and Local Social Capital. Journal of Agricultural and Applied Economics 42, 143-159

Kaiser, H.F. (1970) A second generation Little Jiffy. Psychometrika, 35, 401-415.

Koenker, R., and G. S. Bassett (1978) Regression Quantiles, Econometrica, 46, 33-50.

Leardini and Rossi (2007) Aspetti critici del bilancio di esercizio delle fondazioni di origine bancaria, Rirea, Rome

Magrini, S. (2007) Analysing convergence through the Distribution Dynamics Approach: Why and How?, DSE Working Paper 13.

Malecki E. (2012) Regional Social Capital: Why it Matters, Regional Studies, 46(8): 1023-39

Marrocu, E., and R. Paci, (2012) Different tourists to different destinations. Evidence from spatial interaction models, Working Paper CRENoS 2012-10, Centre for North South Economic Research, University of Cagliari and Sassari.

Mauro, L., and Carmeci, G. (2007) A poverty trap of crime and unemployment, Review of Development Economics, 11, 450- 462.

Mazzola, F. Di Giacomo, G. Epifanio, and R. Lo Cascio, (2012) Territorial Capital and the Great Recession: A Nuts-3 Analysis for Central and Southern Italy. Paper presented at the European Regional Science Association (ERSA) 2012 Annual Conference, Bratislava.

Micucci G., Nuzzo G. (2005) La misurazione del capitale sociale: un'analisi sulle regioni italiane, in Signorini F. - Omicciolo M. (eds), Economie locali e competizione globale, Bologna, Il Mulino, 2005, 207-250.

Milligan, K., E. Moretti and P. Oreopoulos (2004) Does education improve citizenship? Evidence from the United States and the United Kingdom, Journal of Public Economics, 88, 1667-1695.

Morana C., (2004) Regional convergence in Italy: 1951 - 2000, Giornale degli Economisti e Annali di Economia, 63, n.2, 139-160

OECD (2001), Territorial Outlook, Paris

Peiró-Palomino, J., and Tortosa-Ausina E. (2015) Social Capital, Investment and Economic Growth: Some Evidence for Spanish Provinces Spatial Economic Analysis, 10, 102-126. DOI:10.1080/17421772.2014.899387

Peiró-Palomino, J. (2016), Social Capital and Economic Growth in Europe: Nonlinear Trends and Heterogeneous Regional Effects. Oxford Bulletin of Economics and Statistics. doi: 10.1111/obes.12131

Peri, G. (2004), Socio-Cultural Variables and Economic Success: Evidence from Italian Provinces 1951-1991, Berkeley Electronic Journal, Topics in Macroeconomics, 4, 1.

Perucca, G. (2013) The Role of Territorial Capital in Local Economic Growth: Evidence from Italy, European Planning Studies , 21 (4), 502-521.

Putnam, R.D. (1993) Making democracy work: Civic traditions in modern Italy, Princeton, NJ, Princeton University Press. 
Righi, A., (2013) Measuring social capital: Official statistics initiatives in Italy, Social and Behavioral Sciences, 72, 4, 22.

Righi, A., and Turi M., (2007) Una matrice di indicatori per il benchmarking del capitale sociale nelle regioni italiane, Rivista Scienze Regionali, 6(2), 111-136

Rizzi P., (2004) Sviluppo locale e capitale sociale: il caso delle regioni italiane, in Bollino G. e Diappi L., Innovazioni metodologiche nelle scienze regionali (eds), Franco Angeli, Milano.

Rizzi P., and S. Popara (2006) Il capitale sociale: un'analisi sulle province italiane, Rivista di Economia e Statistica del Territorio, 1: 67-86.

Sabatini, F. (2006) The Empiric Social Capital and Economic Development: A Critical Perspective, Fondazione ENI Enrico Mattei Nota di Lavoro, 15.

Sirven N, and Debrand T (2011) Social Capital and health of older europeans: Individual Pathways to Health Inequalities, Gerontologist, 51, 217-217.

Tura, T. and Harmaakorpi, V. (2005) Social capital in building regional innovative capability, Regional Studies 39: 1111-1125.

Vaona, A. (2008) Regional evidence on financial development, finance term structure and growth, Empirical Economics, 34, 185-201.

Walsh, John E. (1959), Large Sample Nonparametric Rejection of Outlying Observations, Annals of the Institute of Statistical Mathematics, Vol. 10 No. 3, 223-232.

WTTC (2012), Travel and Tourism. Economic Impact, Italy.

Woolcock M. (1998), Social capital and economic development: toward a theoretical synthesis and policy framework, Theory and society, 27, 151-208. 